\title{
Efforts to Improve Roadway Safety: A Collaborative Approach between Amish Communities and a Professional Engineering Society
}

S. Dee Jepsen ${ }^{1}$

Associate Professor

Department of Food, Agricultural, and

Biological Engineering

The Ohio State University

\author{
Andrew J. Mann \\ Lecturer and Research Associate \\ Department of Food, Agricultural, and \\ Biological Engineering \\ The Ohio State University
}

\begin{abstract}
Lighting and marking recommendations for animal-drawn buggies and wagons were first established in 2001 through an American Society of Agricultural and Biological Engineers (ASABE) Engineering Practice, EP576.1. Many Anabaptist communities who primarily rely on animal-drawn vehicles utilize this practice for marking their buggies and wagons; however they do not utilize the practice for their low-profile vehicles, such as pony carts. Visibility for pony carts on public roads is important to protect the operators, typically women and children. Following a series of tragic deaths in their community, the Holmes and Wayne Counties, Ohio, Amish safety committee raised the concern of having a consistent lighting and marking scheme for these lowprofile vehicles. They also called for an additional aerial device to boost the cart's visibility to the motoring public. This project took approximately two years to develop consensus among Anabaptist stakeholders and members of the professional engineering society. The result of this effort was a revised Engineering Practice, EP576.2, which enhanced the previous recommendations to include consistent lighting and marking of low-profile animal-drawn vehicles.
\end{abstract}

\section{Keywords}

Amish; Lighting and marking; Animal-drawn vehicle; Low-profile vehicle; Pony cart; Slowmoving vehicle

\section{Acknowledgements}

This study was completed by The Ohio State University's Agricultural Safety and Health program using federal allocations from USDA National Institute of Food and Agriculture. The authors would like to acknowledge the Amish safety committee in Holmes and Wayne Counties, Ohio, for initiating the project, safety committees in both Elkhart and LaGrange Counties, Indiana, and Lancaster County, Pennsylvania, in addition to those attending the national meeting of Amish safety committees. The authors further acknowledge the efforts of the American Society of Agricultural and Biological Engineering (ASABE) Machinery Systems (MS-23/4/3) - Lighting and Marking committee. 


\section{Introduction}

The horse is the main mode of transportation for the Amish, and as a result, shares the roadway with higher-speed motorized vehicles. This interaction increases the opportunity for crashes and personal injury. The Ohio Department of Public Safety's (ODPS) Crash Statistics System shows an average of 146.8 crashes between automobiles and animal-drawn vehicles annually from 2010 to 2014 (Ohio Department of Public Safety 2015). While this number represents less than one percent of all crashes in Ohio ( $0.02 \%$ to $0.03 \%$ annually), the percentage of injury and fatality crashes is much higher for animal drawn vehicle crashes than automotive passenger vehicle crashes. ${ }^{2}$

The American Society of Agricultural and Biological Engineers (ASABE) established an Engineering Practice for animal-drawn buggies and wagons in 2001. Complementing existing laws, rules, and regulations in individual states, provinces, and municipalities, the recommended practice established an identification system for slow-moving animal-drawn vehicles on public roadways (ASABE Standards 2008). Outreach efforts introduced the Amish to the new practice. In the end, however, adoption varied by place, culture, and - notably - vehicle type. Even in communities that generally adopted the recommended lighting and marking schemes, the Amish did not translate these practices onto their low-profile vehicles (see the example in Figure 1). Of concern, these low-profile pony carts were often operated on public roadways by children as young as eight years of age (Jepsen, Henwood, Donnermeyer, and Moyer 2012).

While the original recommended practice was revised in 2008, it did not address lowprofile carts. Following tragic events involving pony carts and motor vehicles, the Ohio Amish safety committee of Holmes and Wayne Counties requested assistance in developing a standardized set of practices they could use for low-profile vehicles. From this request, a needs assessment was designed to determine the scope of the need for lighting and marking improvements. A separate analysis identified potential marking schemes and sought consensus from Amish community leaders and the ASABE to update Engineering Practice 576.1.

A social marketing model directed the standard revising process. Social marketing is the practical application of commercial marketing strategies toward the analysis, planning, execution, and evaluation of programs (Andreasen 1995). It directs an audience to voluntarily accept, reject, or modify a behavior for the benefit of individuals, groups, or society as a whole (Kotler, Roberto and Lee 2002). Beaudreault, Jepsen, and Dellinger (2009) used this technique to design safety education programs for Ohio Anabaptist youth. In the present study, we apply the model to a roadway safety consensus document, seeking solutions that conform to the users' beliefs while remaining consistent with the ASABE professional standards. Within the broader concept of social marketing, the project team employed collaborative decision-making approaches to establish agreement at multiple milestones throughout the project. 


\section{Figure 1. Pony Cart in LaGrange County, Indiana Prior to the Revised Engineering Practice}

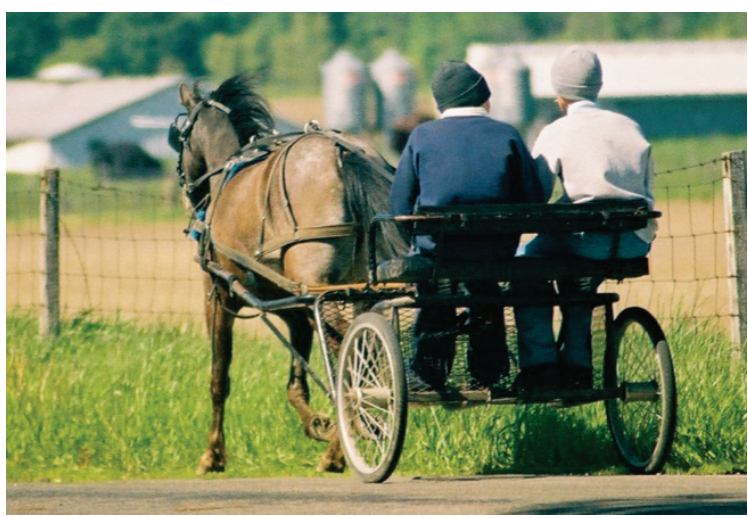

Photo Credit: Cory Anderson

\section{Background}

\section{Rationale for a Revised Lighting and Marking Standard}

A preliminary roadway safety analysis was conducted in Ohio prior to the adoption of the original ASABE Engineering Practice (EP). The Amish communities in Holmes and Wayne Counties, Ohio, were involved in much of the evidence building. A report by the Ohio Department of Transportation (ODOT) in 2000 identified three primary causes of crashes involving motorized vehicles and animal-drawn buggies: (1) motor vehicle drivers underestimating speed differential between their automobile and the horse drawn vehicle, (2) lack of visibility of the horse and buggy between dusk and dawn or because of the rolling terrain; and (3) vehicle action by both motor vehicles and buggies (i.e. not signaling, sudden or unexpected stops, etc.) (Office of Urban and Corridor Planning 2000). These concerns are consistent with findings elsewhere; the sooner a motor vehicle driver can identify a slowmoving, animal-drawn vehicle, the more time the driver has to react (Anderson 2014a).

Many Anabaptists in Wayne and Holmes Counties participate in community events such as "Health and Safety Days" and "Family Farm Field Days" (Beaudreault, Jepsen, and Dellinger 2009). These events attract hundreds of Anabaptist families, including Amish community members, to learn more about safety and health issues. Outreach resources are disseminated and other health services are presented during these public events. Since adoption of the first ASABE Engineering Practice, roadway safety topics have been included in these community safety forums. Popular roadway safety activities include mock crashes and lighting / marking demonstrations at dusk and in darkened barns. ${ }^{3}$

\section{Recommendations for Successful Collaborations in Amish Communities}

Kraybill and Gilliam (2012) present several intervention strategies when working with Amish. These include using face-to-face contact with the target population, developing culturally 
specific illustrations and materials, incorporating visual examples into experience-oriented programs, and working with safety committees. Cognizant that many Anabaptists receive formal education to the eighth grade level, researchers and resource developers need to recognize this audience is more likely to read a directly worded, plain fact sheet from an Amish safety committee rather than a high gloss color fact sheet with a university logo (Fisher, Hupcey, and Rhodes 2001; Jepsen, et al. 2012; Jones and Field 2002). Learning tactics that have been successful in previous topics help future safety campaigns in their endeavors.

\section{National Engineering Standards}

Members of professional societies such as the ASABE develop standards, filling gaps in the current body of knowledge. The ASABE is an international, scientific, and educational organization dedicated to the advancement of engineering systems of agriculture, food systems, and biological systems. Its 9,000 members from more than 100 countries are consultants, managers, researchers, and others who have training and experience to understand the interrelationships between technology and living systems (ASABE 2011).

Many ASABE documents are developed through consensus and in accordance with American National Standards Institute (ANSI) procedures. After a problem is identified and discussed within a convened committee, the ASABE develops a proposal and votes it into existence as a standard. Upon ratification and cataloging, the standard may remain unchanged for an extended period, especially without stakeholders or committee members expressing a need for update. The organization has more than 240 published standards; conformance is voluntary except where governmental regulations require it.

\section{Methods}

The Ohio State University Extension's Agricultural Safety and Health program has a long-standing reputation of partnering with Ohioan Amish safety committees. This project was initiated as a result of that pre-established relationship with the Holmes and Wayne Counties Amish safety committee. A fatality incident in 2010 involving three young children operating a low-profile pony cart prompted the two entities to work together to address a safety concern.

The Social Cognitive Theory (Bandura 1995) guided this research. Three key factors of this theory are: the environment, the person, and a behavior. In this study, the environment takes into consideration the roadway, the low-profile pony cart, and physical factors in the geographic location. The person represents the Amish community, including their beliefs about, knowledge of, and attitude toward the lighting and marking seen by motorists. The behavior involves the Engineering Practice and all of its caveats imposed with practicing the recommendations. This theory consists of many other constructs, including observational learning, behavioral capability, expectations, reinforcement, self-efficacy, and emotional coping responses. However, these additional tenants were not measured during the consensus building process and could be incorporated at a later date to guide program evaluation and adoption efforts. 
The study's research design consists of mixed-methods. Working collaboratively with the Amish community and the professional engineering society responsible for lighting and marking standards, we outlined and implemented a five-step intervention process over several years (Figure 2). These steps included: (1) a needs assessment; (2) identification of potential lighting and marking schemes; (3) establishing consensus among the various stakeholders; (4) revision of an existing standard practice; and (5) dissemination of the standard information to encourage voluntary adoption of a uniform lighting and marking practice for animal-drawn vehicles.

\section{Needs Assessment}

A review of previously released Ohio crash statistics and injury reports was completed. In particular, the ODPS roadway crash statistics were analyzed to determine if other low-profile vehicle incidents were a concern beyond Holmes and Wayne Counties.

Anecdotal comments received at the onset of the project suggested that pony carts were only used by children for recreational purposes on the farm, and that these carts typically did not go on the road. To guide formal discussion about pony cart use on the road, a five-item questionnaire was developed for use at face-to-face meetings with Amish community members. The questions asked their level of agreement / disagreement with the following statements: (1) pony carts are common in my area; (2) there is a need for lighting and marking on pony carts; (3) pony carts in my area are clearly marked and can easily be seen in the daylight; (4) pony carts are not worth investing much money in their lighting and marking; and (5) pony carts are used for recreation, do not go far from home, or are not often used on public roadways.

Researchers used Ohio Amish contacts to create a list of Amish safety committees across North America. This list was used to arrange meetings with Amish safety committee members, manufacturers, and salesmen of pony carts in Indiana, Ohio, and Pennsylvania.

\section{Potential Lighting and Marking Schemes}

The Engineering Practice 576.1 standard, other roadway and industry applications (e.g. agriculture and construction equipment), and an online search of lighting and marking devices guided the development of lighting and marking options for low-profile vehicles. An undergraduate student completing an individual study project initiated the online search. The student searched for items that were (a) practical, (b) affordable, and (c) conformed to Amish beliefs. Lighting and marking devices were purchased and mounted to a display board to produce visual representations of the potential marking schemes.

Six additional questions addressing the types of reflective material and lighting on carts were added to the needs assessment instrument. These questions were asked during the lighting demonstration, which typically occurred in a parking lot or shop. 


\section{Figure 2. Project Timeline}

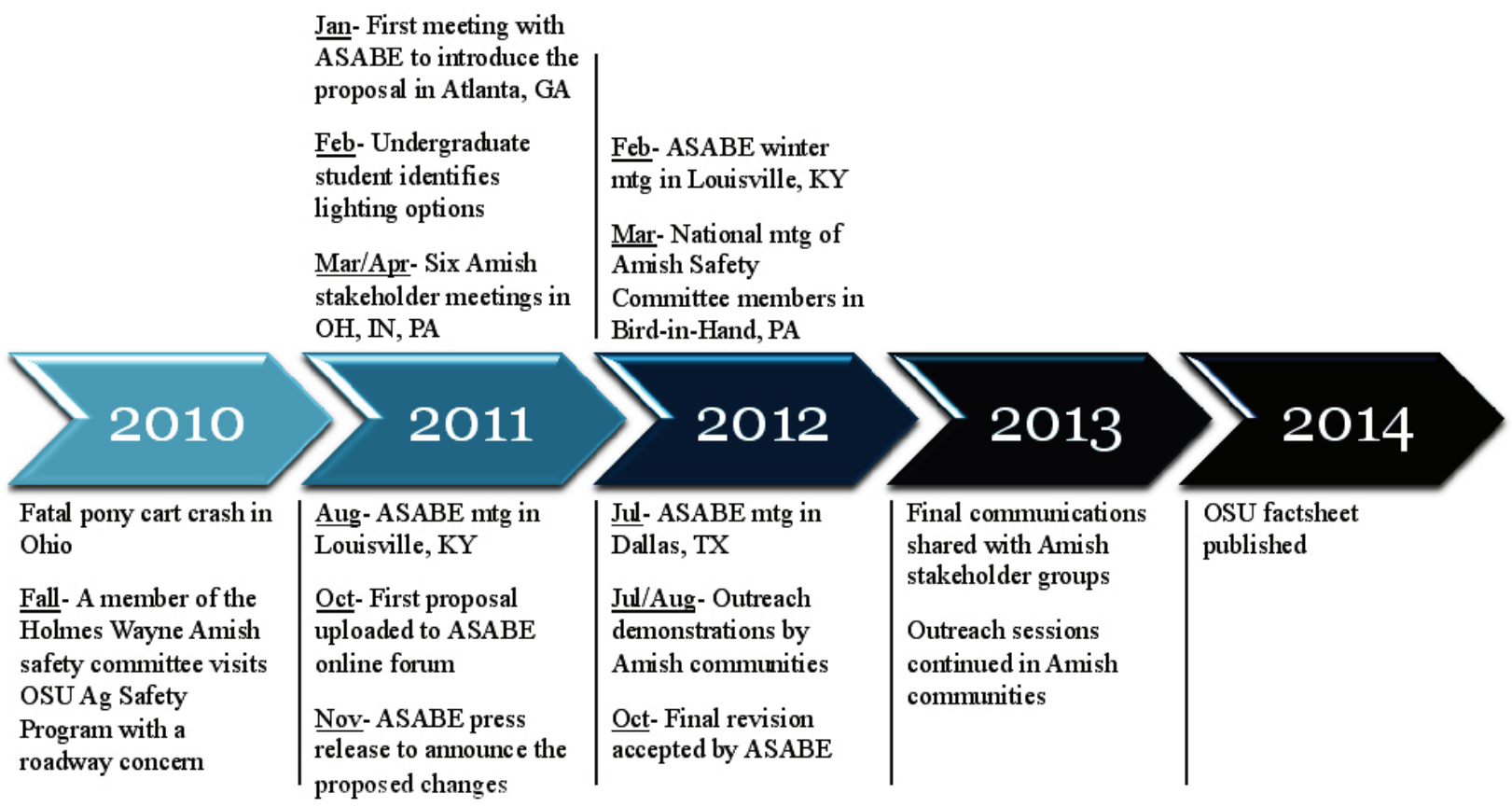

\section{Establishing Consensus to Revise the ASABE 576.1 Lighting and Marking Recommended Practice}

The consensus-building phase was designed to identify culturally appropriate solutions that increase low-profile animal-drawn vehicle visibility. Amish from a single Ohio settlement initiated the idea, but to make a large-scale change to an existing national standard required input and acceptance across multiple Amish communities.

Amish stakeholders contributed to the consensus via face-to-face conversation and orally administered questionnaires. Face-to-face meetings were facilitated in six highly populated Amish communities with safety committee members, pony cart manufacturers, and pony cart salesmen $(n=23)$. Acknowledging the Amish as a patriarchal society, researchers interacted and received comments mostly from men. Each meeting was conducted informally. Per the literature about working with Anabaptist populations (Jones and Field 2002), Amish stakeholders were addressed in informal, personal settings; researchers avoided a patronizing attitude or the image of the "outside expert." After introductions, the research team used a series of questions to guide the discussion. Based on prior experiences, the researchers collected feedback through discussion and documented comments following the meetings.

After collecting data from the Amish stakeholders, the research team met with the ASABE Machinery Systems — Lighting and Marking committee (MS-23/4/3) during the Annual International Meeting (AIM) in Louisville, KY, in July 2011. A pre-proposal to change the current EP576.1 standard was presented under "new business." It included results from the 
literature review and the Amish stakeholder meetings. Following this meeting, an online forum was used to post documents, record discussion, and ballot the proposed revision.

Next, hard copies of all project documents were mailed to Amish safety committee leaders in Illinois, Indiana, Iowa, Ohio, and Pennsylvania. Many leaders had attended at least one face-to-face meeting and were thus familiar with the project. However, they did not have the collective results from all Amish meetings. ASABE meeting minutes were also shared with these stakeholders.

In February 2012, the research team addressed the ASABE MS-23/4/3 committee once more at the Agricultural Equipment Technology Conference (AETC) in Louisville, KY. This venue permitted face-to-face discussion and updates from the online forum, in addition to any additional communication from Amish stakeholders.

Just a few months after the ASABE AETC event, an opportunity arose to present the collective work to the national gathering of Amish safety committees. At this meeting, 55 Amish safety committee members from Illinois, Indiana, Iowa, Kentucky, Michigan, Ohio, Pennsylvania, and Ontario met with the project team and one ASABE Lighting and Marking committee member. This outreach effort allowed members from both groups to discuss results and answer questions. After the project team left, the Amish continued their discussions about the draft proposal privately and provided follow-up comments later.

At the July 2012 Annual International Meeting (AIM) in Dallas, TX, the research team met with the ASABE MS-23/4/3 - Lighting and Marking committee one final time. Information about the consensus reached at the national Amish safety committee meeting was shared.

\section{Revision of a Lighting and Marking Standard}

ASABE Standardization Procedures, per section " 8.5 - Standards approvals and reports," guided the revision. The process included submission of proper forms, verbal progress reports at biannual committee meetings, standards development committee balloting, written response to all "disapproval" voters, and feedback to the key stakeholders. The MS-23/4/3 committee met face-to-face every six months, but also communicated via email and a members-only online forum. The ASABE website provided space for researchers to upload communication documents from Amish stakeholders, for ASABE committee members to make comments on these documents, and finally, for members to cast votes in favor of or against the proposed revisions (with an option to abstain). The research team had to address "against" and "abstain" votes, as consensus was necessary for the standard revision to be accepted.

\section{Final Dissemination of Information}

Following the ASABE Lighting and Marking committee's approval of the revised practice, the project team launched an outreach effort to communicate the information to end- 
users and multiple key stakeholder groups in North America. The team used a practice similar to the first animal-drawn engineering practice effort from 2008. The research team developed a fact sheet detailing the new lighting and marking scheme, which Amish communities could reference.

In summary, the project team developed a mixed-method approach to qualitatively and quantitatively identify the need for a standardized lighting and marking practice for low-profile carts. A timeline of the project activities is presented in Figure 2.

\section{Results}

The results of this study included consensus for a standardized lighting and marking scheme, revision of an existing standard engineering practice for lighting and marking of animaldrawn vehicles, and dissemination of information to key stakeholders. For the most part, consensus building and information dissemination took place simultaneously and within similar networks; therefore, these two sections are combined here.

\section{Needs Assessment}

To guide their roadway safety campaign, the Ohio Agricultural Safety and Health program used surveillance data collected and reported by the ODPS. The ODPS reports contain animal-drawn vehicle crash data aggregated as "Animal with Buggy, Wagon or Surrey." Unfortunately, the ODPS database does not distinguish between a buggy or pony cart; the generalized code classification is "animal-drawn vehicle." Table 1 shows the frequency of Ohiobased animal-drawn vehicle crashes (figures are per units involved, not number of incidents) from 2005 to 2014; a five-year average is reported in Table 1 for 2010 through 2014.

Animal-drawn vehicles do not have the same safety features as a modern day automobile; thus, injury and fatality rates are much higher for animal-drawn vehicles (Table 1) when compared to passenger vehicles (Table 2). From 2010 to 2014, those involved in an animaldrawn vehicle crash were 1.7 times more likely to be injured in a crash $(26.0 \%$ vs. $44.9 \%)$, and over five times more likely to be in a fatal crash $(0.25 \%$ vs. $1.42 \%)$ when compared to passenger vehicle crashes. Ohio has just over two deaths per year on average for animal-drawn vehicle passengers (Ohio Department of Public Safety 2015). No noticeably high frequency of pony cart related fatalities appeared in crash reports. However, the Anabaptist communities hold youth safety in high regards. One life lost is too many, especially if the incident could have been prevented.

A five-item questionnaire guided face-to-face meetings with 23 Amish safety committee members, pony cart manufacturers, pony cart dealers, and other community members in three states. Table 3 shows the results: $91 \%$ of respondents agreed that pony carts were common in their area and $96 \%$ agreed that there is a need for lighting and marking on these vehicles. A high majority indicated conspicuity products must be reasonably priced for a pony cart that does not get as much road travel as their other horse-drawn buggies and wagons. Eight participants noted 
Table 1. Frequency of Animal-Drawn Vehicles Crashes in Ohio, 2005-2014

\begin{tabular}{llllll} 
Year & $\begin{array}{l}\text { Fatal Crashes } \\
\text { (count) }\end{array}$ & $\begin{array}{l}\text { Fatal Crashes } \\
\text { (\% of total) }\end{array}$ & $\begin{array}{l}\text { Injury Crashes } \\
\text { (count) }\end{array}$ & $\begin{array}{l}\text { Injury Crashes } \\
\text { (\% of total) }\end{array}$ & $\begin{array}{l}\text { Total } \\
\text { (count) }\end{array}$ \\
\hline 2005 & 1.0 & 0.68 & 69.0 & 46.9 & 147 \\
\hline 2006 & 4.0 & 3.28 & 58.0 & 47.5 & 122 \\
\hline 2007 & 3.0 & 2.68 & 49.0 & 43.8 & 112 \\
\hline 2008 & 2.0 & 1.47 & 53.0 & 39.0 & 136 \\
\hline 2009 & 2.0 & 1.34 & 65.0 & 43.6 & 149 \\
\hline 2010 & 3.0 & 2.26 & 60.0 & 45.1 & 133 \\
\hline 2011 & 1.0 & 0.61 & 77.0 & 47.2 & 163 \\
\hline 2012 & 0.0 & 0.00 & 70.0 & 44.9 & 145 \\
\hline 2013 & 4.0 & 2.76 & 67.0 & 46.2 & 137 \\
\hline 2014 & 2.0 & 1.46 & 56.0 & 40.9 & 147 \\
\hline $5-Y r$ Avg. & 2.0 & 1.42 & 66.0 & 44.9 &
\end{tabular}

Table 2. Frequency of Passenger Vehicle Crashes in Ohio, 2010-2014

\begin{tabular}{llllll} 
Year & $\begin{array}{l}\text { Fatal Crashes } \\
\text { (count) }\end{array}$ & $\begin{array}{l}\text { Fatal Crashes } \\
\text { (\% of total) }\end{array}$ & $\begin{array}{l}\text { Injury Crashes } \\
\text { (count) }\end{array}$ & $\begin{array}{l}\text { Injury Crashes } \\
\text { (\% of total) }\end{array}$ & $\begin{array}{l}\text { Total } \\
\text { (count) }\end{array}$ \\
\hline 2010 & 1,182 & 0.24 & 124,415 & 25.7 & 484,782 \\
\hline 2011 & 1,137 & 0.24 & 124,214 & 25.7 & 482,948 \\
\hline 2012 & 1,258 & 0.27 & 120,981 & 25.9 & 466,408 \\
\hline 2013 & 1,169 & 0.27 & 116,810 & 26.8 & 435,295 \\
\hline 2014 & 1,157 & 0.25 & 117,405 & 25.8 & 454,527 \\
\hline $5-Y r$ Avg. & 1,181 & 0.25 & 120,765 & 26.0 & 464,792 \\
$2010-2014$ & & & & &
\end{tabular}

Table 3. Quantitative Results of Face-to-Face Questions ( $=23)$

Key Points Discussed*

Agree Disagree Unsure

\begin{tabular}{lccc} 
& Count (\%) & Count (\%) & Count (\%) \\
\hline Pony carts are common in my area. & $21(91)$ & $2(9)$ & 0 \\
\hline There is a need for lighting and marking on pony carts. & $22(96)$ & $1(4)$ & 0 \\
\hline $\begin{array}{l}\text { Pony carts are not worth investing much money in lighting } \\
\text { and marking (marking kit must be "reasonably priced") }\end{array}$ & $21(100)$ & 0 & 0 \\
\hline Pony carts do not go far from home & $8(100)$ & 0 & 0 \\
\hline
\end{tabular}

*Not all 23 participants provided a comment to each item. 
that pony carts are not used for longer distance travel. No comments were collected on the question, "Pony carts in my area are clearly marked and can easily be seen in the daylight"; researchers surmise that the Amish did not want to express disagreement until the meeting was concluded.

\section{Identification of potential lighting and marking schemes}

Lighting and marking devices were placed on a prototype pony cart seat back for discussion at the face-to-face meetings. (The prototype seat was easier to transport to Amish communities than an actual pony cart.) The display contained three aerial devices: an orange bicycle flag, a glow whip (typically used on dune buggies and all-terrain vehicles), and a lighted pole (commonly used on boats and construction equipment). The wooden board representing a pony cart seat back had Velcro retroreflective tape marking strips that could be easily rearranged. Based on cultural appropriateness, a more progressive scheme of red and orange retroreflective tape was used, or a more conservative scheme of white/silver. Later, an Ohio pony cart manufacturer used the stakeholder decisions to develop pony cart conspicuity kits for display in Amish dealer shops.

Table 4 shows the response tallies to questions posed at demonstrations. The area of most agreement (78\%) was that reflective tape and a slow-moving vehicle (SMV) emblem were inadequate for visibility; however, sufficient surface area to affix marking tape and mount an SMV emblem was often mentioned as an issue. Second, $72 \%$ agreed that lights should be installed on the vehicles if they were to be used during times of low visibility, such as in fog or at dawn/dusk.

\section{Table 4. Quantitative Results of Face-to-Face Questions (N=23)}

Key Points Discussed

Marking (reflective tape and an SMV emblem) is all that is needed for a pony cart to be visible from a distance. Lights should be installed on pony cars so they are visible

Agree Disagree Unsure Count $(\%)$ Count $(\%)$ Count $(\%)$

$2(11) \quad 14(78) \quad 2(11)$
during dusk and at night.

Properly marking pony carts is difficult due to their size (too small to mark properly)

A tall (5 feet or taller) flag should be used on pony carts to 5 (26) $4-6 \mathrm{ft}$ make them more visible. 5 (26) $6-8 \mathrm{ft}$

0 0 $8(47)$

$1(5) \quad 8(42)^{*}$

The lighted flags (glow whip and pole light) would be acceptable in my community.

$15(71)$

$6(29)$

0

The lighted flags (glow whip and pole light) are too expensive to install on a pony cart.

\footnotetext{
* Totals may not add to $100 \%$ due to rounding. Not all 23 participants provided a comment to each item.
} 
Lighted poles and glow whips received much attention during demonstrations but were later discounted. Besides being costly up-front investments, battery expenses added additional expense. Additionally, these items were unlikely to be widely and consistently accepted across Amish communities due to cultural factors; thus, they scored lower than bicycle flags.

The statement, "A tall (5 feet or taller) flag should be used on pony carts to make them more visible," generated discussion and conflicting views. Stakeholders living near flat terrain indicated that a shorter flag (four to six feet tall), approximately eye level with a motorist, would provide the best visibility for low-profile vehicles. Those living in hilly terrain indicated that a taller flag (six to eight feet tall) would allow for quicker notification of the animal-drawn vehicle in their areas. For this reason, flag heights of four to six feet and six to eight feet above the road were discussed. Of the ten people who indicated at least a four feet high flag was needed, half agreed $(n=5)$ that four to six feet high was the optimum height. This indicated that flexibility was needed for flag height.

\section{Establishing Consensus to Revise the ASABE 576.1 Lighting and Marking Recommended Practice}

\section{Amish population}

Locations of the seven face-to-face meetings with Amish stakeholders (six face-to-face meetings, plus the national Amish safety committees meeting) are summarized in Table 5. Discussion focused on the use of pony carts in different communities and the perceived need for a low-profile vehicle lighting and marking standard. Individuals were shown the various lighting and marking schemes on the pony seat prototype and were asked to discuss what features seem to be advantageous in their region.

ASABE made a public media announcement regarding the proposed changes to the engineering practice (Appendix A). They targeted rural newspapers, where animal-drawn vehicles were prominent. In an effort to reach more members of the Anabaptist communities, the same information was also sent to The Budget newspaper. Following the media release, letters were drafted and sent to 25 Amish safety committee members in Illinois, Indiana, Iowa, Kentucky, Ohio, and Pennsylvania. The letters described the changes to the standard and invited any final feedback prior to submission to the ASABE MS-23/4/3 Lighting and Marking committee for vote.

A final outreach opportunity arose near the project's end. The team was invited to the annual national meeting of Amish Safety committees to present the findings and progress of the lighting and marking project. This venue provided one last face-to-face discussion between project team members and the Amish end-users. A member of the ASABE Lighting and Marking committee who also resided near to where the meeting occurred accompanied the project team. He brought to the discussion the perspective of a professional engineer, a motor vehicle operator, 


\section{Table 5. Face-to-face Meeting Locations and Participant Demographics}

\begin{tabular}{|c|c|c|c|}
\hline County, State & Participant Demographics & $\begin{array}{l}\text { Number of } \\
\text { Participants }\end{array}$ & General Comments \\
\hline Elkhart Co., IN & $\begin{array}{l}\text { Equipment manufacturer and } \\
\text { dealer }\end{array}$ & 1 & \\
\hline LaGrange Co., IN & Amish safety committee & 6 & $\begin{array}{l}3 \text { male committee } \\
\text { members accompanied } \\
\text { by their wives who also } \\
\text { provided comments }\end{array}$ \\
\hline Wayne Co., OH & $\begin{array}{l}\text { Equipment manufacturer and } \\
\text { dealer }\end{array}$ & 3 & \\
\hline Holmes Co., OH & Amish safety committee & 3 & \\
\hline Hardin Co., $\mathrm{OH}$ & Equipment manufacturers & 2 & $\begin{array}{l}* \text { Older Order Amish } \\
\text { community }\end{array}$ \\
\hline Lancaster Co., PA & $\begin{array}{l}\text { Amish safety committee, } \\
\text { equipment manufacturers, and } \\
\text { dealers }\end{array}$ & 8 & \\
\hline Lancaster Co., PA & $\begin{array}{l}\text { National Meeting of Amish } \\
\text { safety committees }\end{array}$ & 55 & $\begin{array}{l}\text { Committee members } \\
\text { from the states of IA, } \\
\text { IL, IN, KY, MI, PA, } \\
\text { and Ontario, Canada }\end{array}$ \\
\hline
\end{tabular}

*Old Order Amish are known for their technological conservatism. A comment was made during this meeting "The lighting and marking [suggestions] seem like good ideas, but the bishops around here would not likely accept this much change."

and a resident in a heavily Amish populated community. During the discussion, the ASABE member was asked his perception of implementing specific recommendations from the proposed standard revision. Clarification on technical details such as speed differential (how fast an automobile approaches a slow-moving vehicle) and perceived visibility of a bicycle-type flag on a low-profile animal-drawn vehicle added credibility to the discussion. Once the project team left, the Amish safety committees continued private discussions, later submitting their conclusions (Table 6). In several group discussions, the Amish stakeholders believed it was important to incorporate the language "bicycle flag or alternative aerial device..." in the revised standard. By including this additional language, future products could be developed and marketed to meet the criteria of the new standard.

\section{Professional society}

The majority of communication with the ASABE MS-23/4/3 Lighting and Marking committee took place via email and through a secure members-only online forum. Face-to-face communication with the engineering professionals was possible at two Agricultural Equipment Technology Conferences (AETC) and two Annual International Meetings (AIM) of ASABE. 


\section{Table 6. Results from Amish Safety Committees at National Meeting $(\mathbf{N}=\mathbf{5 5})$}

\begin{tabular}{llll} 
Key Points Discussed & $\begin{array}{l}\text { Agree } \\
\text { Count (\%) }\end{array}$ & $\begin{array}{l}\text { Disagree } \\
\text { Count (\%) }\end{array}$ & Unsure \\
\hline Low-profile vehicles (pony carts) should be marked with: & & & \\
\hline Slow-Moving Vehicle (SMV) emblem & $55(100)$ & 0 & 0 \\
\hline Flag or similar aerial device & $55(100)$ & 0 & 0 \\
\hline Reflective tape along back and sides & $55(100)$ & 0 & 0 \\
\hline Amber lights, if used at dusk/after dark & $55(100)$ & 0 & 0 \\
\hline $\begin{array}{l}\text { An alternative aerial device to the bicycle flag should be } \\
\text { developed (by the Amish communities) }\end{array}$ & $33(66)$ & $22(34)$ & 0 \\
\hline
\end{tabular}

\section{Table 7. Summary of Ballot for X576.2 - Lighting and Marking of Animal- Drawn Equipment}

\begin{tabular}{|l|l|l|l|}
\hline $\begin{array}{l}\text { Voting Options of Members } \\
\text { (MS-23/4/3) }\end{array}$ & $\begin{array}{l}\text { Votes with no } \\
\text { comments, Count }\end{array}$ & $\begin{array}{l}\text { Votes with } \\
\text { comments, Count }\end{array}$ & $\begin{array}{l}\text { Total, Count } \\
\text { (\% of total) }\end{array}$ \\
\hline Approval votes & 20 & 4 & $24(67)$ \\
\hline Disapproval votes & 0 & 2 & $2(5.5)$ \\
\hline Abstain & 0 & 1 & $1(2.5)$ \\
\hline Did not vote & 9 & 0 & $9(25)$ \\
\hline GRAND TOTAL & 29 & 7 & $36(100)$ \\
\hline
\end{tabular}

\section{Revision of a Lighting and Marking Standard}

After three of the meetings, the proposal was put forth on ballot to the MS-23/4/3 committee. The format for clearly organizing the proposed revision was communicated to the committee through use of a three column Word document, with each column containing; current language of EP576.1 (existing standard), proposed language of X576.2, and reason for any changes. Table 7 shows results from the first committee vote.

From the 36-person membership, $67 \%(\mathrm{~N}=36)$ of the total committee and $89 \%(\mathrm{n}=24)$ of those casting votes accepted the proposal as drafted. Prior to acceptance, all disapproval votes had to be addressed in writing. The research team first contacted disapproval voters via phone to discuss their concerns and determine plausible solutions. One disapproval voter was concerned about the technical explanation of certain terminology in the proposed document; their concerns were mitigated through edits. The other disapproval voter had philosophical objections to the revision based on the grounds that people, specifically Anabaptists, should have a right to choose if they want to comply with this recommended practice, and individuals should not be penalized. Written information was provided to this voter stating that the Amish stakeholders acknowledged certain Anabaptist groups would be unlikely to adopt the recommended practices. The Amish stakeholder meetings lent support to the recommended practice as a suggested 


\section{Figure 3. Lighting and Marking Scheme for Low-Profile Pony Carts}

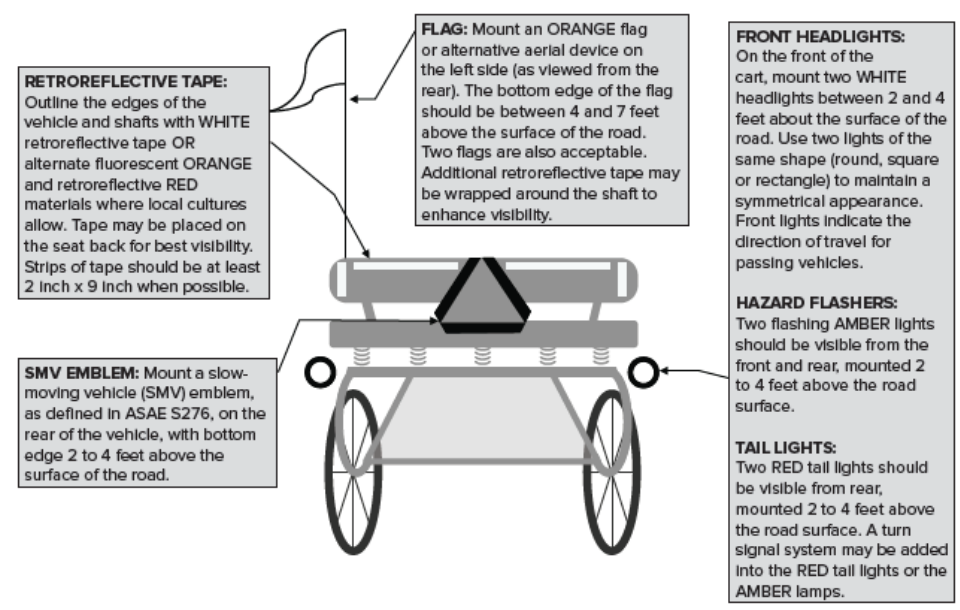

standardized method for marking low-profile animal-drawn vehicles, and there has never been any intent to make the recommendation into a regulation.

Additional edits were documented using blue font in the three-column document that contained current language of EP576.1, proposed revisions, and reason for the change. This document and the written responses to disapproval votes were distributed to MS-23/4/3 committee members. A second vote was cast, resulting in $96 \%(n=25)$ agreement and $4 \%(n=1)$ disagreement, with one member abstaining. The proposed revisions were reviewed one additional time at a face-to-face meeting of ASABE and accepted as EP576.2.

The adopted marking scheme for low-profile vehicles is presented in Figure 3. It consists of: an SMV emblem rear-mounted two feet from the road's surface, at least one flag or alternative aerial device mounted four to seven feet from the road's surface, rear mounted retroreflective tape (red and orange where local culture allows, with a provision for white), and side mounted yellow retroreflective tape. Amber hazard flashers, white front-facing head lights, and red rear-facing tail lights are recommended for enhanced visibility and at times of low visibility.

\section{Final Dissemination of Information}

An OSU Extension fact sheet (Appendix B) was developed to simplify the revised technical standard's language for EP576.2. The Amish drafted their own fact sheet, "Buggy/Pony Cart Lighting and Marking Recommendations," following an OSU Extension fact sheet created for the original EP576.1 standard. The Amish safety committee's fact sheet contained direct, personalized language:

Let us remember the privilege we as a community have that we are allowed to share the road with motorists. With all privileges comes responsibility. Let us take our 
responsibility seriously. Please take time to review the attached recommendations for lighting and marking on buggies and pony carts. The more uniform our buggies and pony carts are lit, the easier it will be for motorists to identify us as a buggy. Thank you for your support! (Holmes and Wayne Counties Amish safety committee 2012).

Based on the social influence components of social marketing and social cognitive theories, live demonstrations were conducted within Amish community in the summer of 2012. Demonstrations showed the new pony cart lighting and marking. The Amish safety committees conducted their own pony cart demonstrations, illustrating the difference between properly and improperly marked vehicles and the consequences for road travel.

The first Ohio demonstration was held at the 2012 Family Farm Field Day. Nearly 800 plain Anabaptists were in attendance. Demonstrations were conducted using a properly equipped pony cart. A boy drove the cart around the arena while an announcer discussed the lighting and marking features. Further, over 300 fliers about the standard revisions were disseminated. The second Ohio demonstration was later that summer at the Holmes County Amish Health and Safety Day. Approximately 1,500 people attended. With booths set up, local health departments, law enforcement entities, and others promote healthy living and safe work practices. The lighting and marking display took place inside a long barn. The barn was sealed, creating a dark environment. Headlights from a stationary motor vehicle were directed at the far end of the structure, shining on pedestrians, bicycles, buggies, and low-profile pony carts. The demonstration contrasted individuals and vehicles that were not marked with any reflective materials or lights with those wearing proper clothing for the environment (e.g. reflective vests) or properly lit and marked buggies and pony carts. Another 500 fliers were disseminated at this event. During each of these Ohio outreach events, many positive comments were received, indicative of strong approval for these efforts to protect people driving pony carts.

This project's collective efforts brought two societies together: Amish stakeholders and a professional engineering society. By working independently yet through familiar processes, both developed plausible solutions for a roadway safety issue.

\section{Discussion}

An Ohio Amish safety committee initiated this study, with their desire to have a recommended practice for consistent lighting and marking of low-profile vehicles. The original ASABE EP576.1 standard provided general recommendations for animal-drawn vehicles but did not provide specific language regarding low-profile vehicles such as pony carts. Even where communities had fully adopted lighting and marking practices on larger animal-drawn vehicles, they did not consistently mark pony carts. Amish communities had proposed different ways to enhance the visibility of low-profile vehicles, but these proposals were not consistent and did not implement the recommendations of EP576.1. 


\section{Figure 4. Low Profile Pony Carts in Ohio after Adoption of Engineering Practice 576.2}
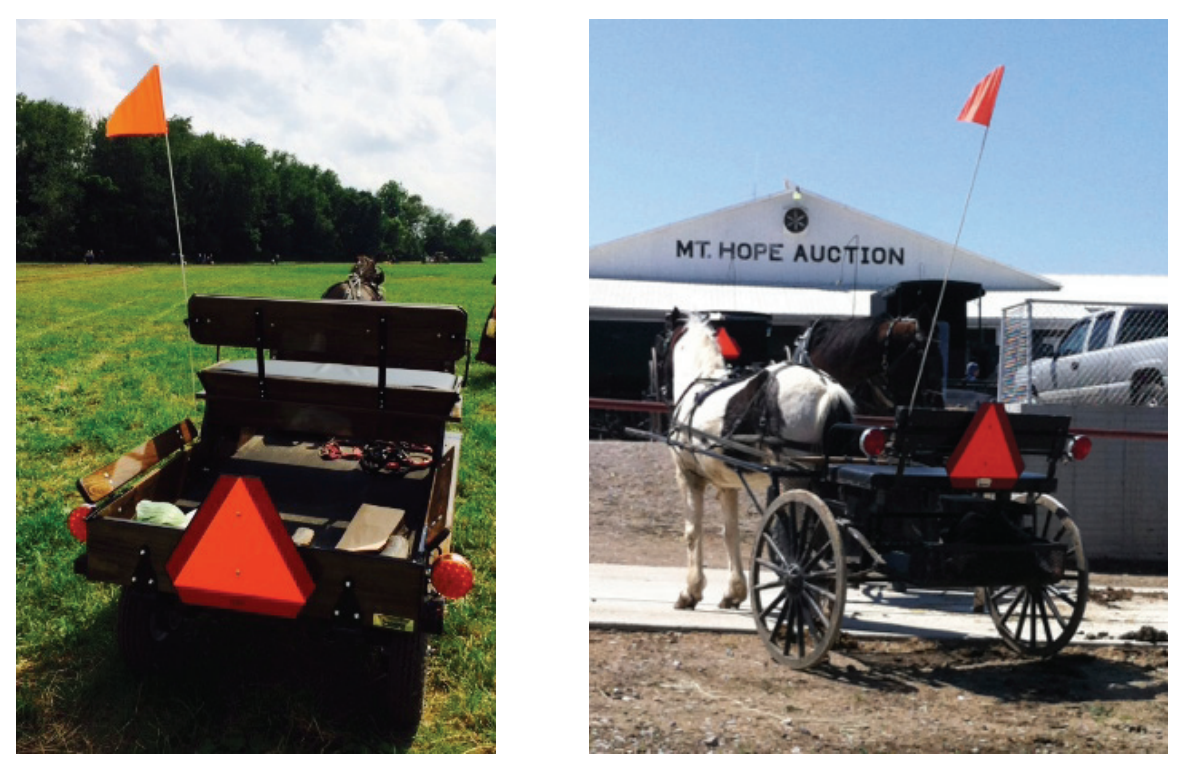

Photo Credits: Dee Jepsen

The target audience for this project included highly populated Amish communities in Indiana, Ohio, and Pennsylvania. The primary method of contact and dissemination was through the Amish safety committees. Establishing a relationship with these committee leaders allowed researchers to gain their trust and receive contact information of other community members, pony cart manufacturers, and salesmen in their region. The project team accepted an invitation to present at the national meeting of the Amish safety committees, establishing additional rapport with Amish stakeholders in other geographic locations. The project team consistently presented the draft proposal as objectively as possible, giving credit to the Ohio Amish committee members that first suggested the need for more attention to pony carts. Each opportunity to discuss the roadway safety topic increased trustworthy collaborations among researchers and stakeholders, and, in turn, greatly increased this project's potential reach.

The lighting and marking scheme developed for the new EP576.2 incorporated all existing elements from the previous standard for the low-profile carts, ensuring consistency with lighting patterns on larger wagons and buggies. These materials include a rear-mounted SMV emblem, rear and side mounted retroreflective tape, and lights when the vehicle is operated at night or in low visibility conditions (Figure 4). The new, pony cart-specific additions to the standard also included at least one flag or aerial device mounted four to seven feet from the ground. Industry manufacturers may develop new products to satisfy the aerial device requirement; the market for these products will likely be driven by cultural acceptance.

The process of building consensus with various stakeholders is thoroughly established in the literature. While strict protocols were followed to ensure channels of communication were 
open, establishing consensus and agreement is not intuitive. During the process, a colleague cautioned the project team not to interpret head nods and kind comments as agreement. They may be smiling and nodding to be polite and respectful, but are not necessarily ready to adopt the products. The researchers feel confident that this issue was at least partially resolved through continuous communication, a written response following each meeting, and the national Amish safety committees' recommendation to adopt the proposed revisions.

Amish communities are grounded on certain religious beliefs, including the desire not to draw attention. For that reason, more conservative Amish sects do not use flashing lights or colorful markers. Of course, the goal of lighting and marking products is to attract attention of motorists, who, upon recognition of the buggy, can adjust their speed. The SMV emblem is possibly the most controversial and exclusively debated marking device on animal-drawn vehicles, even resulting in legal conflicts (Anderson, 2014b; Garvey, 2003; Harkness and Stuckey, 1963; Kroeker and Mann, 2010; Lehtola, 2007). Many Amish safety committee members were from communities that had the SMV emblem and lighting on buggies and wagons. Other Amish communities view the lighting and marking practices of these Amish as progressive. Other than the Hardin County, Ohio settlement, no other such conservative communities were engaged in this study. As the standard is most likely to be adopted in the more progressive Amish communities - and with no intent to enact these recommendations as lawthe researchers sought recommendations useful and acceptable to end-users. Additionally, the ASABE organization is credited with promoting the SMV emblem; any suggested marking scheme without this emblem would not have been accepted by the ASABE MS-23/4/3 Lighting and Marking committee.

Further research should explore methods for quantifying lighting and marking effectiveness for animal-drawn vehicles. This could be accomplished through monitoring the adoption of lighting and marking practices and through surveillance of county-specific crash statistics.

\section{Endnote}

${ }^{1}$ Contact information: S. Dee Jepsen, Department of Food, Agricultural, and Biological Engineering, Agricultural Engineering Building, 590 Woody Hayes Dr., Columbus, OH 43210; jepsen.4@osu.edu

${ }^{2}$ In 2014, crashes involving animal with buggy, wagon, or surrey represented $0.03 \%$ of the total crashes in Ohio, compared to passenger vehicles representing 90.4\% respectively. Of the animaldrawn vehicle crashes, $1.46 \%$ resulted in a fatality and $40.9 \%$ resulted in an injury. This compares to $0.25 \%$ of passenger vehicle crashes resulting in a fatality, and $25.8 \%$ with a reported injury.

${ }^{3}$ During a midday lighting and marking demonstration near Mt. Hope, OH, the local Amish safety committee and volunteers covered all windows and openings of a barn with black opaque 
material. Participants (usually 10 to 20) entered the open door of the barn, the door was closed, and various lighting and marking configurations were demonstrated.

${ }^{4}$ For different buggy configurations, see Anderson (2014).

\section{References}

Anderson, Cory. 2014a. "Horse and Buggy Crash Study I: Common Crash Scenarios between a Motor Vehicle at the Amish/Old Order Mennonite Horse and Buggy." Journal of Amish and Plain Anabaptist Studies 2(1):79-99.

Anderson, Cory. 2014b. "Horse and Buggy Crash Study II: Overstretching the Slow-Moving Vehicle Emblem's Abilities: Lessons from the Swartzentruber Amish." Journal of Amish and Plain Anabaptist Studies 2(1):100-15.

Andreasen, Alan. 1995. Marketing Social Change: Changing Behavior to Promote Health, Social Development, and the Environment. San Francisco, CA: Jossey-Bass.

ASABE. 2011. "ASABE Announces Project to Revise Animal-Drawn Equipment Lighting and Marking Standard.” News Release. St. Joseph, MI: ASABE.

ASABE Standards. 2008. EP576.1: Lighting and Marking of Animal-Drawn Equipment. St. Joseph, MI: ASABE.

Bandura, Albert (ed). 1995. Self-Efficacy in Changing Societies. New York, NY: Cambridge University Press.

Beaudreault, Amy, Dee Jepsen, and Wayne Dellinger. 2009. "Designing an Agricultural Safety Intervention Program for Ohio Amish Youth.” Cases in Public Health Communication \& Marketing 3:38-58.

Fisher, Kathleen, Judith Hupcey, and Denise Rhodes. 2001. "Childhood Farm Injuries in Old Order Amish Families.” Journal of Pediatric Nursing 16(2):97-101.

Garvey, Philip. 2003. "Motorist Comprehension of the Slow-Moving Vehicle (S.M.V.) Emblem." Journal of Agricultural Safety and Health 9(2):159-69.

Harkness, Ken, and William Stuckey. 1963. Effective Approaches to Reducing Accidents Involving Slow Vehicles on Highways: An Interim Report. Columbus, OH: Ohio State University.

Holmes and Wayne Counties Amish safety committee. 2012. Buggy/Pony Cart Lighting and Marking Recommendations. Locally published fact sheet. 
Jepsen, S. Dee, Kathy Henwood, Joseph Donnermeyer, and Kay Moyer. 2012. "Identifying Culturally and Age Appropriate Farm Safety Curricula for Amish and Other Conservative Anabaptist Youth. Journal of Agricultural Safety and Health 18(1):57-67.

Jones, Paul, and William Field. 2002. "Farm Safety Issues in Old Order Anabaptist Communities: Unique Aspects and Innovative Intervention Strategies." Journal of Agricultural Safety and Health 8(1):67-81.

Kotler, Philip, Ned Roberto, and Nancy Lee. 2002. Social Marketing: Improving the Quality of Life $\left[2^{\text {nd }}\right.$ ed.]. Thousand Oaks, CA: Sage Publications.

Kraybill, Donald, and Jerene Gilliam. 2012. "Culturally Competent Safety Interventions for Children in Old Order Anabaptist Communities. Journal of Agromedicine 17(2):24750 .

Kroeker, Annette, and Daniel Mann. 2010. "Motorist Comprehension of the Slow-Moving Vehicle Emblem in Manitoba." Journal of Agricultural Safety and Health 16(2):11125.

Lehtola, Carol. 2007. "Slow to Catch On to the Slow-Moving Vehicle Emblem." Journal of Agricultural Safety and Health 13(1):5-7.

Office of Urban and Corridor Planning. 2000. Amish Buggy Safety on Ohio State Roadway System: Analysis and Action Plan. Columbus, $\mathrm{OH}$ : Department of Transportation.

Ohio Department of Public Safety. 2015. Ohio Traffic Crash Facts 2010-2015. Columbus, OH: Department of Transportation. 


\section{Appendix A: ASABE News Release}

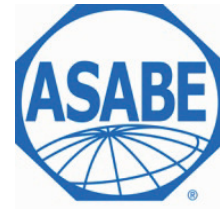

American Society of

Agricultural and Biological Engineers

News Release
CONTACT

Dolores Landeck

269-932-7039

landeck@asabe.org

FOR IMMEDIATE RELEASE

November 1, 2011

\section{ASABE Announces Project to Revise Animal-Drawn Equipment Lighting and Marking Standard}

ST JOSEPH, MICHIGAN - The American Society of Agricultural and Biological Engineers (ASABE) has initiated a project to revise ANSI/ASAE EP576.1, Lighting and Marking of Animal-Drawn Equipment.

The currently published standard has effective recommendations for animal-drawn wagons and buggies. However, safety professionals working with Anabaptist communities have identified additional recommendations that are needed for various low-profile wagons operating on public roads, including pony carts, which are commonly operated by children.

ASABE is recognized worldwide as a standards developing organization for food, agricultural, and biological systems, with more than 240 standards currently in publication. Conformance to ASABE standards is voluntary, except where required by state, provincial, or other governmental requirements, and the documents are developed by consensus in accordance with procedures approved by the American National Standards Institute. For information on this or any other ASABE standard, contact Scott Cedarquist at ASABE, 269-932-7031, cedarq@asabe.org. A current listing of all ASABE standards projects can be found on the ASABE web site at http://www.asabe.org/standards/projects,-adoptions,-revisions,-withdrawals.aspx

The American Society of Agricultural and Biological Engineers is an international scientific and educational organization dedicated to the advancement of engineering applicable to agricultural, food, and biological systems. Its 9,000 members, from more than 100 countries, are consultants, managers, researchers, and others who have the training and experience to understand the interrelationships between technology and living systems. Further information on the Society can be obtained by contacting ASABE at (269) 429-0300 (phone) or (269) 429-3852 (fax); hq@asabe.org. Details can also be found at http://www.asabe.org/. 


\section{Appendix B: OSU Extension Fact Sheet}

\section{Lighting and Marking}

\section{Recommendations for Pony Carts and Other Low-Profile, Animal-Drawn Vehicles}

S. Dee Jepsen, Associate Professor, and Andrew "Dewey" Mann, Lecturer, Depar tment of Food, Agricultural and Biological Engineering, The Ohio State University

Low-profile vehicles suchaspony carts driven onpublic roadways create unique safety concerns for both those driving the vehicle as well as for passing motorists. Pony carts in Amish communities are often driven by younger childrenwho maynothave as much experience operating on roads as those driving larger buggies and wagons. A motorist could easily be traveling more than 10 times faster than the speed of a pony cart.

\section{Working with Rural Communities}

The Holmes and Wayne counties Amish Safety committeescontactedTheOhio State University's Agricultural Safety and Heal th program to discuss the need for enhanced lighting and marking on low-profile carts. After meeting with more than 85 community members, pony cart manufacturers and dealers, recommendations were developed for an improved lighting and marking practice for pony carts.

\section{Revision of a National Stand ard}

A national standard issued through the American Society of Agricultural and Biological Engineers (ASABE) had already existed for larger buggies and wa gons since 2001. This national practice was revised to include lowprofile vehicles, specifically pony carts. The goal was to provide a standardized recommendation with the intent of enhancing the visibility of individuals who operate pony carts on public roads. The key components are described in this fact sheet and summarized in Table 1.

\section{Slow-Moving Vehicle (SMV) Emblem}

The SMV emblem (Fig. 1) is a unique marker identifying vehicles traveling slower than $25 \mathrm{mph}$. Studies show that two out of three highway crashes involving slow-moving vehicles are rear-end collisions. The majority of these rear-end collisions occur during daylight hours. During the day, the bright, nonreflective orangetriangle of the SMV emblem gains the attention of approaching motorists from more than 1,000 feet away. This provides a dvance warning to motoriststhat are approaching a slower moving vehicle. At night, the reflective border of the SMV emblem glows brightly in the path of approaching headlights.

A full-sized SMV emblem should be mounted on the rear center of the vehicle, with the triangle point facing upward, 2-4 feet ab ove the surface of the road.

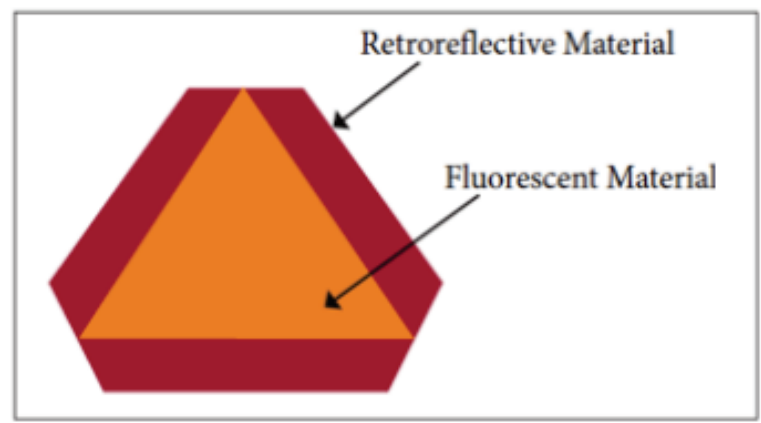

Figure 1. Slow-Moving Vehide(SMV) Emblem. 


\section{Flag or Alternative Aerial Device}

TheSMVemblem is documented as effective when it is visible, especially whenvehicles are approaching on flat terrain and straightsections ofroadway. Toprovide greater visibility of low-profile vehicles on curves and over hilltops, an orange flag should be mounted on the left side of the cart. The approximate mounting height of the flag should be 4-7 feet above the surface of the road, and will depend on the terrain in that area. For example, carts driven in flat, open areas should mount a flag that is about 4 feet from surface of the ground to the bottom edge of the flag. If the cart is driven in a region with more hills, a flag that extends 6-7 feet above the road surface may be more effective.

Community safety leaders have also suggested wrapping retroreflective tape around the shaft of the flag pole for added visibility.

Orange flags will typically fade and should be replaced every year as needed. Weather and direct sunlight tend to cause more extensive fading over time. It is often difficult to tell how faded a flag is until holding a new flag next to the old one. Community leaders areworking with product engineersto develop a medium-cost alterative to the orange flag that will not fade as easily over time.

\section{Retroreflective Tape}

Mounting reflective tape to a low-profile vehicle can be more difficult than fastening to a larger vehicle such as a buggy, but is just as important. Current retroreflective tape is effective in daylight and at night.

A study conducted by the National Highway Traffic Safety Administration (www-nrd.nhtsa.dot.gov/ Pubs/809222.pdf) found that use of retroreflective tape reduced the number of side and rear impacts into heavy semi trailers by 29 percent. This group also estimated that the use of reflective tape could reduce the number of collisions by 7,800 per year. Knowledge about how tape can be used to increase the visibility of semi trailers can be applied to pony carts.

The rear-facing edges of the pony cart should be outlined with retroreflective tape to get the attention of passing motorists. In addition, yellow retroreflective tape should be placed along the vehicle tongue or shaft, visible on the outside of the animal.

4. Lights (if cart is driven during low-light hours such as at dawn, dusk or night.)

Most pony carts and other low-profile vehicles are driveninthe summer and are primarily operated during the daylight. Animal-drawn vehicles can be equipped with a battery-operated lighting system. Adding lights such as amber hazard flashers, small headlights and red taillights will provide the best option for maximum visibility during all conditions.

\section{Conclusion}

This recommended practice establishes a unique identification system for slow-moving, animal-drawn vehicles on public roadways. It is intended that this identification system be used to complement existing laws, rules and regulations in individual states, provinces and municipalities.

It is recognized that this recommended practice can raise cultural or religious issues and is not intended to devalue or replace those values. It is intended to provide options to those who would like to add orenhance lighting and marking of their animal-powered vehicles in the form of a voluntary consensus standard.

\section{References}

ANSI/ASAE, EP576. 2 October 2012, Lighting and Marking of Animal-Drawn Equipment, ASAE Standards, American Society of Agricultural Engineers (ASAE), St. Joseph, MI 49085.

National Highway Traffic Safety Administration (NHTSA), The Effectiveness of Retroreflectie Tape on Heavy Trailers, NHTSA Technical Report, National Highway Traffic Safety Administration, Springfield, VA 22161.

\section{Resources}

ANSVASABE S608, Headlamps for Agricultural Equipment

Flashing Warning Lamp for Agricultural Equipment, SAE $J 974$

Headlamps for Agricultural Equipment, SAE J975 Slow Moving Vehicle (SMV) Emblem, American Society of Agricultural Engineers, ASAE S276

Reflex Reflectors, SAE J594

Retroreflective Material and Lighting and Marking of Agricultural Equipment on Highways, ASAE S279

Storage Batteries, SAE J537

Tail Lamps (Rear Position Lamps) for Use on Motor Vehicles Less Than 2032 mm in Overall Width, SAE J585

For additional information, visit agsafety.osu.edu or request a listing of the available fact sheets from your local OSU Extension office.

\section{Aclnowledgments}

Reviewed by Ann Christy, PhD, Department of Food, Agricultural and Biological Engineering, The Ohio State University, and Kay Moyer, Lancaster County Extension, Penn State University. 


\begin{tabular}{|c|c|c|c|c|}
\hline \multirow[t]{2}{*}{ Item } & \multicolumn{3}{|c|}{2012 ASABE Recommendations } & \multirow[t]{2}{*}{ Options } \\
\hline & Number & Color & Mounting & \\
\hline $\begin{array}{l}\text { SMV Emblem } \\
\text { (Rear-Mounted) }\end{array}$ & 1 & $\begin{array}{l}\text { RED retroreflective } \\
\text { border surrounding } \\
12 \text {-inch nonreflective } \\
\text { fluorescent ORANGE } \\
\text { center }\end{array}$ & $\begin{array}{l}\text { Rear center, bottom } \\
\text { edge, } 2-4 \text { feet from } \\
\text { the surface of the road }\end{array}$ & $\begin{array}{l}\text { Full-sized SMV tri- } \\
\text { angle; no acceptable } \\
\text { alternatives }\end{array}$ \\
\hline Flag & At least 1 & $\begin{array}{l}\text { White pole with } \\
\text { ORANGE flag at top of } \\
\text { pole }\end{array}$ & $\begin{array}{l}\text { If } 1 \text { flag used, mount } \\
\text { on left side (from rear } \\
\text { of the cart), bottom } \\
\text { edge of flag } 4-7 \text { feet } \\
\text { high from surface of } \\
\text { road } \\
\text { If } 2 \text { flags used, mount } \\
\text { on each side of cart }\end{array}$ & $\begin{array}{l}\text { Illuminated type } \\
\text { (lighted) flags or poles } \\
\text { with an AMBER lamp } \\
\text { should be used for } \\
\text { vehicles driven under } \\
\text { low-visibility condi- } \\
\text { tions (i.e., dusk)' }\end{array}$ \\
\hline $\begin{array}{l}\text { Retroreflective } \\
\text { Material (Rear) }\end{array}$ & $\begin{array}{l}\text { At least six } 1 \text {-inch wide } \\
\times 3 \text {-inch long strips }\end{array}$ & $\begin{array}{l}\text { Alternating RED } \\
\text { retrore flective and } \\
\text { ORANGE nonreflective } \\
\text { fluoresent material }\end{array}$ & $\begin{array}{l}\text { Outline sides of the } \\
\text { vehicle; tape may be } \\
\text { placed on seat back } \\
\text { for best visibility }\end{array}$ & $\begin{array}{l}\text { Whe re local culture } \\
\text { uses WHITE retro- } \\
\text { reflective material, it } \\
\text { should be AT LEAST } \\
\text { 1-inch wide }\end{array}$ \\
\hline $\begin{array}{l}\text { Retroreflective } \\
\text { Material (Each Side) }\end{array}$ & $\begin{array}{l}\text { At least three } 1 \text {-inch } \\
\text { wide } \times 3 \text {-inch long } \\
\text { strips }\end{array}$ & YELLOW & $\begin{array}{l}\text { Symmetrically along } \\
\text { the vehicle tongue or } \\
\text { shaft, vis ible on the } \\
\text { outs ide of the animal. }\end{array}$ & $\begin{array}{l}\text { Where local culture } \\
\text { uses WHITE retro- } \\
\text { reflective material, it } \\
\text { should be AT LEAST } \\
\text { 1-inch wide }\end{array}$ \\
\hline $\begin{array}{l}\text { Hazard Flashers1 } \\
\text { (Front and Rear) }\end{array}$ & At least 2 & AMBER & $\begin{array}{l}\text { Symmetrically as } \\
\text { widely spaced as pos- } \\
\text { sible, mounted } 2-4 \\
\text { feet high from surface } \\
\text { of road }\end{array}$ & $\begin{array}{l}\text { No other options exist } \\
\text { for AMBER flashing } \\
\text { lamps }\end{array}$ \\
\hline Headlights1 (Front) & At least 2 & WHITE & $\begin{array}{l}\text { Symmetrical, mounted } \\
2-4 \text { feet high from } \\
\text { surface of road }\end{array}$ & $\begin{array}{l}\text { As an alternative to } \\
\text { headlights and tail- } \\
\text { lights, at least two } \\
\text { double-faced lamps } \\
\text { protruding from the } \\
\text { sides at the widest } \\
\text { point can be used }\end{array}$ \\
\hline Tail Lights1 (Rear) & At least 2 & RED & $\begin{array}{l}\text { Symmetrically as } \\
\text { widely spaced as pos- } \\
\text { sible, mounted } 2-4 \\
\text { feet high from surface } \\
\text { of road }\end{array}$ & $\begin{array}{l}\text { A turn signal system } \\
\text { may be added into } \\
\text { the RED tail lamps or } \\
\text { the flashing AMBER } \\
\text { lamps; the turn side } \\
\text { lamp should flash and } \\
\text { the other lamp should } \\
\text { go to a steady burn }\end{array}$ \\
\hline
\end{tabular}




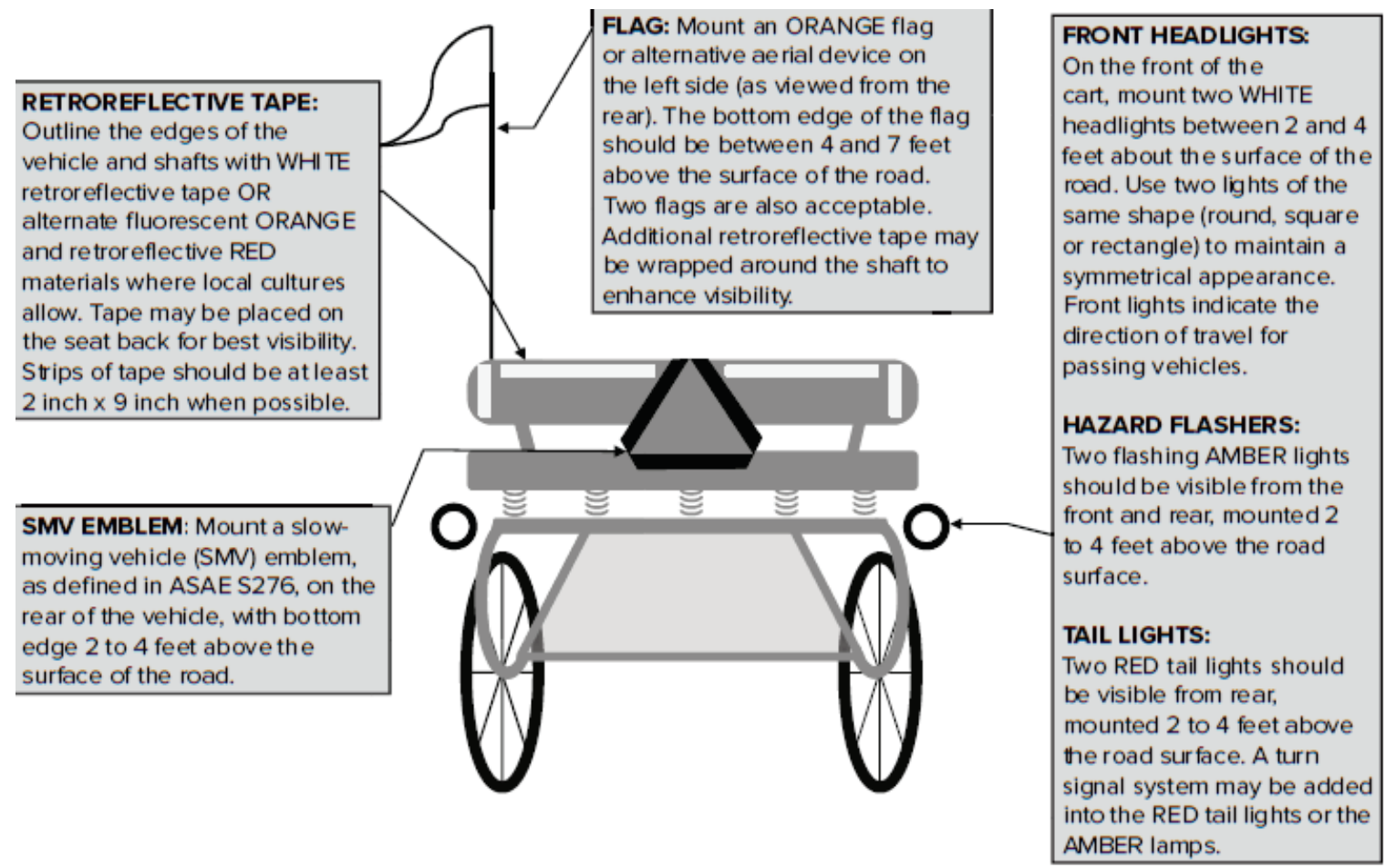

Ohio State University Extension embraces human diversity and is committed to ensuring that all research and related educational programs are available to clientele on a nondiscriminatory basis without re gard to age, ancestry, $\infty$ lor, disability, gender identity $\alpha$ expression, genetic information, HN/AIDS status, military status, national $\alpha$ rigin, race, religion, sex, sexual orientation, $\alpha$ veteran status. This statement is in accordance with United States Civil Rights Laws and the USDA.

Keith L. Smith, Associate Vice President for Agricultural Administration; Assodate Dean, College of Food, Agricultural, and Environmental Sciences; Director, Ohio State University Extension; and Gist Chair in Extension Education and Leadership.

For De af and Hard of Hearing. ple ase contad Ohio State University Extension using your preferred communication (e-mail, relay services, $\alpha$ video relay services). Phone 1-800-750-0750 between 8 am. and 5 p.m. EST Monday through Friday. In form the operator to dial 614292-6181.

Copyright $₫ 2014$, The Ohio Sta teUniversity 